\title{
Proneuropeptide Y Processing in Large Dense-Core Vesicles: Manipulation of Prohormone Convertase Expression in Sympathetic Neurons Using Adenoviruses
}

\author{
Luc Paquet, ${ }^{1}$ Bernard Massie, ${ }^{2}$ and Richard E. Mains ${ }^{1}$ \\ ${ }^{1}$ Department of Neuroscience, The Johns Hopkins University School of Medicine, Baltimore, Maryland, 21205-2185, and \\ 2Institut de Recherche en Biotechnologie, Conseil National de Recherches du Canada, Montréal, Québec, Canada
}

The efficient delivery of foreign genes into postmitotic cells is becoming very important for studies of nervous system functions. Cultured sympathetic neurons synthesize neuropeptide $Y$ (NPY) in addition to catecholamines, providing an experimental model for studying neuronal peptide biosynthesis. In this work, we have studied the biosynthetic processing of NPY in primary cultures of rat superior cervical ganglion (SCG) neurons. NPY activation is complex, requiring sequential actions of a prohormone convertase (PC), carboxypeptidase $H$, and peptidylglycine $\alpha$-amidating mono-oxygenase. Northern analyses established that SCG neurons in the animal contain mRNAs for both PC1 and PC2, and simultaneous immunocytochemistry for NPY and PC1 or PC2 established a 1:1 correspondence between NPY and PC2 expression in two thirds of the neurons that express NPY, both in the animal and in tissue culture. Biosynthetic studies on proneuropeptide $Y$ (pro-NPY) process- ing to mature NPY established a close similarity to the rates seen in endocrine cells expressing PC2 and established clear differences between the patterns in SCG neurons and in endocrine cells expressing PC1. Recombinant adenoviruses were used to increase the level of PC1 in the cultured neurons from negligible to a level comparable with the level of PC1 in the anterior pituitary, and pro-NPY processing was markedly accelerated. When the viruses were used to lower the endogenous PC2 levels, using an antisense construct, pro-NPY processing was retarded. Taken together, these results support a major role for PC2 as the pro-NPY converting enzyme, and they establish the cultured SCG neurons as a model to study neuronal peptide biosynthesis.

Key words: neuropeptide $Y$; prohormone convertase 2; superior cervical ganglion; adenovirus; temperature block; AtT-20; GH3; antisense
Tissue culture of dissociated superior cervical ganglion (SCG) neurons has proven to be an excellent model for studying transmitter phenotype plasticity in response to the cellular environment (Landis, 1994). In culture, these neurons exhibit their distinctive morphology with appropriate compartmentalization of several marker proteins (Higgins et al., 1988). Like most neurons, SCG neurons express multiple transmitters. These neurons are noradrenergic and also express neuropeptides such as neuropeptide Y (NPY), enkephalin, somatostatin, vasoactive intestinal peptide (VIP), and substance P (SP) (Marek and Mains, 1989, 1990; Nawa and Sah, 1990). Sympathetic neurons have at least two classes of secretory vesicles: small dense-core vesicles (SDCVs) and large dense-core vesicles (LDCVs) (Landis, 1978). SDCVs are specialized catecholaminergic vesicles, responsible for fast signaling in the nervous system (Scheller, 1995). LDCVs store and secrete catecholamines and peptide neurotransmitters such as

\footnotetext{
Received Aug. 14, 1995; revised Nov. 6, 1995; accepted Nov. 8, 1995.

This work was supported by NIH Grant DA-00266 and a grant from the Canadian Medical Research Council. We thank the following people: Drs. Betty Eipper, An Zhou, and Martin Schiller for many helpful discussions; Maude Simoneau and Julie Dionne for help with constructing adenovirus recombinants; Carla Berard for help with tissue culture; Dr. An Zhou for creating the AtT-20-NPY line; Dr. Victor May for help with SCG culture; Dr. Story Landis for the initial guinea pig NPY antiserum; and Edwin Chang and Marie Bell for general laboratory assistance. The mouse 7B2 cDNA was kindly provided by Dr. Majambu Mbikay (Institut de Recherches Cliniques de Montréal).

Correspondence should be addressed to Richard E. Mains, Department of Neu roscience. The Johns Hopkins University School of Medicine, 725 North Wolfe Street, Baltinore MD 21205-2185.

L.P. is a postdoctoral fellow of the Canadian Medical Research Council. Copyright $\odot 1996$ Society for Neuroscience $0270-6474 / 96 / 160964-10 \$ 05.00 / 0$
}

NPY; they can be seen as the neuronal equivalent of endocrine secretory granules.

NPY is a highly conserved 36 -amino-acid amidated peptide. In SCG neurons, it produces a presynaptic dose-dependent reduction in the release of norepinephrine and modulates a variety of postsynaptic targets (Dumont et al., 1992; Wahlestedt and Reis, 1993). Like most peptide hormones, NPY is produced from a larger precursor via the sequential action of endoproteases, carboxypeptidase $\mathrm{H}$, and peptidylglycine $\alpha$-amidating monooxygenase. The latter stcps of NPY biogenesis are well understood, but little is known about the protease(s) responsible for endoproteolysis at the dibasic processing site (tyrosine-glycinelysine-arginine-serine) contained within proneuropeptide $\mathrm{Y}$ (proNPY). A family of subtilisin-related prohormone convertases (PCs) has been identified recently (Lindberg, 1991; Gotoh et al., 1992; Steiner et al., 1992; Bloomquist and Mains, 1993; Van de Ven et al., 1993; Seidah el al., 1994). Two members of this family, PC1 (PC3) and PC2, are expressed primarily in endocrine and neuronal tissues. Manipulation of levels of PC1 and/or PC2 in AtT-20 cells leads to differential processing of pro-opiomelanocortin (POMC). PC1 performs the earliest cleavages and $\mathrm{PC} 2$ performs later cleavages, including several that are normally restricted to the intermediate pituitary (Benjannet et al., 1991; Bloomquist et al., 1991; Thomas et al., 1991; Zhou et al., 1993; Zhou and Mains, 1994).

The processing of pro-NPY has been studied in primary neuronal cultures and in endocrine and nonendocrine cell lines after transfection (Marek and Mains, 1989; Dickerson and Mains, 1990; Wulff et al., 1993; May et al., 1995). The transfection experiments 
demonstrated that cleavage of pro-NPY occurred in endocrine cells expressing either $\mathrm{PC} 1$ or $\mathrm{PC} 2$. The SCG sympathetic neurons fully process pro-NPY, generating the bioactive peptide (Marek and Mains, 1989), and the endoproteases PC1 and PC2 have been found by Western blot in sympathetic nerve extracts (Egger et al., 1993). It remains to be determined whether these two convertases are expressed in other sympathetic tissues such as the SCG and which one is involved in the processing of pro-NPY. To characterize better the biosynthetic events leading to expression of NPY, we have studied the processing of pro-NPY in primary cultures of sympathetic neurons derived from the $\mathrm{SCG}$, using various manipulations to perturb pro-NPY processing. We conclude that $\mathrm{PC} 2$ is the endoprotease primarily responsible for pro-NPY processing in the SCG under physiological conditions.

\section{MATERIALS AND METHODS}

Cell culture. SCGs from two litters of neonatal rats were dissected and placed in DMEM-air medium (Marek and Mains, 1989). The ganglia (36-50) were diced with a scalpel and dissociated by gentle agitation for $20 \mathrm{~min}$ at $37^{\circ} \mathrm{C}$ in the same medium containing $4 \mathrm{mg} / \mathrm{ml}$ collagenase (Worthington Biochemical, Freehold, NJ), $1 \mathrm{mg} / \mathrm{ml}$ hyaluronidase (type IV-S, Sigma, St. Louis, MO), $0.1 \mathrm{U} / \mathrm{ml}$ benzonase (EM Science, Gibbstown, $\mathrm{NJ}$ ), and $10 \mathrm{mg} / \mathrm{ml}$ fatty acid-free bovine serum albumin (BSA; Sigma). The tissue suspension was rinsed with medium and further dissociated for $15 \mathrm{~min}$ in medium containing $3 \mathrm{mg} / \mathrm{ml}$ trypsin $(1-300 ; \mathrm{ICN}$ Biochemicals, Costa Mesa, CA). The digestion was stopped with DMEM/ F-12 containing $10 \%$ fetal clone serum (HyClone Laboratories, Logan, IIT) and $10 \%$ NuSerum (Collaborative Biomedical, Bedford, MA). The tissue fragments were dispersed by trituration with a fire-polished Pasteur pipette and filtered through a $70 \mu \mathrm{m}$ nylon cell strainer to remove undigested pieces of tissue. The dispersed cells were sedimented and resuspended in DMEM/F-12 containing $10 \%$ fetal clone serum, $10 \%$ NuSerum, $4.8 \mathrm{gm} / 1$ HEPES, $2.2 \mathrm{gm} / 1 \mathrm{NaHCO}, 4.5 \mathrm{gm} / 1$ glucose, $120 \mathrm{mg} / \mathrm{l}$ penicillin, $200 \mathrm{mg} / \mathrm{l}$ streptomycin sulfate, and $100 \mathrm{ng} / \mathrm{ml} 2.5 \mathrm{~S}$ nerve growth factor (NGF; Boehringer Mannheim, Indianapolis, IN) and plated on laminin (Sigma)- or collagen (Collaborative Biomedical)coated dishes. Cytosine arabinofuranoside $(10 \mu \mathrm{M})$ was added during the first week of culture to prevent the proliferation of ganglionic nonneuronal cells. After the first week in culture, the cells were routinely cultured in complete serum-free medium: DMEM/F-12 supplemented with insulin $(10 \mu \mathrm{g} / \mathrm{ml})$, holotransferrin $(20 \mu \mathrm{g} / \mathrm{ml})$, fatty acid-free BSA (1 $\mathrm{mg} / \mathrm{ml}$ ), $10 \mathrm{nM} 3,5,3^{\prime}$-tri-iodothyronine, metal ion mix (Marek and Mains, 1989), and $100 \mathrm{ng} / \mathrm{ml} \mathrm{NGF.} \mathrm{Mouse} \mathrm{corticotrope} \mathrm{AtT-20} \mathrm{cells} \mathrm{and} \mathrm{rat}$ somatomammotrope GH3 cells were grown as described previously (Dickerson and Mains, 1990).

RNA analysis. Tissues dissected from the animal were placed into a guanidium thiocyanate denaturing solution (Chomczynski and Sacchi, 1987). Total RNA was purified from contaminants by phenol/chloroform extraction and isopropanol precipitation. RNA was quantitated by absorbance at $260 \mathrm{~nm}$, and the purity was assessed by the $260 / 280 \mathrm{~nm}$ absorbance ratio. Total RNA $(5-10 \mu \mathrm{g})$ was fractionated on a $0.9 \%$ agarose gel and blotted onto a nylon membrane (Nytran+, Schleicher \& Schuell, Keene, $\mathrm{NH})$ by capillary transfer in $10 \times \mathrm{SSC}(1 \times \mathrm{SSC}=150 \mathrm{mM} \mathrm{NaCl}$, $15 \mathrm{~mm}$ sodium citrate, $\mathrm{pH} 7.0$ ) for $16 \mathrm{hr}$. RNA was cross-linked to the membrane by ultraviolet exposure (Stratalinker, Stratagene, La Jolla, CA). Blots were prehybridized at $65^{\circ} \mathrm{C}$ for $2 \mathrm{hr}$ in $50 \%$ formamide, $5 \times$ $\mathrm{SSC}, 1 \times \mathrm{PE}[1 \times \mathrm{PE}=50 \mathrm{~nm}$ Tris- $\mathrm{HCl}, \mathrm{pH} 7.5,0.1 \%(\mathrm{w} / \mathrm{v})$ sodium pyrophosphate, $1 \%$ SDS, $0.2 \%$ polyvinylpyrrolidone, $0.2 \%$ Ficoll, and 5 $\mathrm{mM}$ EDTA], and $0.1 \mathrm{mg} / \mathrm{ml}$ salmon sperm DNA. The different RNAs were hybridized to uniformly ${ }^{32}$ P-labeled cRNA probe $\left(10^{\circ} \mathrm{cpm} / \mathrm{ml}\right)$ added to the prehybridization mix and incubated overnight at $65^{\circ} \mathrm{C}$. Filters were then washed for $30 \mathrm{~min}$ at $65^{\circ} \mathrm{C}$ in $2 \times \mathrm{SSC}$ and $0.1 \% \mathrm{SDS}$ and for $60-180 \mathrm{~min}$ at $65^{\circ} \mathrm{C}$ in $0.1 \times \mathrm{SSC}$ and $0.1 \% \mathrm{SDS}$. The blots were exposed for times varying from 2 hr to $4 \mathrm{~d}$, and the signals were quantified using a PhosphorImager apparatus (Molecular Dynamics, Sunnyvale, CA).

Immunocytochemistry. Guinea pig antibody to NPY was provided by Dr. Story Landis (Case Western Reserve University School of Medicine); results were confirmed with guinea pig anti-NPY sera that we raised at Hazleton HRP (Denver, PA). Rabbit antiserum to a bacterially expressed fragment of $\mathrm{PC1}$ ( $\mathrm{JH} 700$; raised against $\mathrm{PPC1}$ residues $\mathrm{Leu}^{3 \%}-\mathrm{Glu}^{514}$ ) or affinity-purified rabbit antiserum to a synthetic peptide within PC1
(JH887 and JH888; Milgram and Mains, 1994) and affinity-purified rabbit antiserum to PC2 (JH1159; Zhou and Mains, 1994) were used at a dilution of $1: 5000,1: 100$, and 1:50, respectively. Similar colocalization of PC2 with NPY was also seen using crude PC2 antiserum at 1:1000. Monoclonal antibodies to microtubule-associated protein-2 (MAP-2; Sigma), synapsin (Sigma), and synaptophysin (Boehringer Mannheim) were used at a dilution of 1:1000. SCG cultures or fresh-frozen slices of adult SCG $(10 \mu \mathrm{m})$ were fixed with $4 \%$-formaldehyde in PBS (50 mm sodium phosphate, $150 \mathrm{~mm} \mathrm{NaCl}, \mathrm{pH} 7.4$ ) and permeabilized in the same buffer containing $0.1 \%$ Triton $\mathrm{X}-100$. Nonspecific binding was blocked with $10 \%$ normal goat serum in PBS. The cells were incubated overnight at $4^{\circ} \mathrm{C}$ with the primary antibody diluted in $1 \%$ normal goat serum in PBS. The bound antibody was revealed using fluorescein isothiocyanate-coupled goat anti-guinea pig IgG (BioDesign, Carmel, NY) and Cy3-coupled donkcy anti-rabbit IgG (Jackson Immunoresearch, West Grove, PA) or Cy3-coupled donkey anti-mouse antibodies and mounted with PermaFluor aqueous medium (Immunon, Seattle, WA) containing 1,4diazabicyclo[2.2.2]-octane as an antifading agent (Tausk ct al., 1992).

Western analysis. Extracts of SCG from adult rats and from cultured SCG neurons were analyzed for PC1 and PC2 immunoreactive proteins as described previously (Zhou and Mains, 1994).

Biosynthetic labeling. The biosynthesis of pro-NPY was studied with pulse-chase metabolic labeling. Cells were incubated for $5-10 \mathrm{~min}$ in methionine/cysteine-deficient complete serum-free media (CSFM), labeled for $15 \mathrm{~min}$ with $250 \mu \mathrm{Ci}$ of $\left[{ }^{35} \mathrm{~S}\right] \mathrm{methionine/cystcine} \mathrm{ProMix} \mathrm{(Am-}$ ersham, Buckinghamshire, UK) in CSFM lacking cysteine/methionine, and either harvested immediately (pulse) or chased for various times in complete CSFM (Zhou et al., 1993). Cellular NPY-related peptides were extracted in $5 \mathrm{~m}$ acetic acid/BSA and lyophilized (Dickerson et al., 1990). Phenylmethylsulfonylfluoride $(300 \mu \mathrm{g} / \mathrm{ml})$ and protease inhibitor mix were added throughout the entire extraction procedure to prevent nonspecific proteolysis (Milgram and Mains, 1994). Lyophilized extracts were resuspended, and NPY-related peptides were immunoprecipitated with antiserum JH3 against human NPY (Marek and Mains, 1989). Immunoprecipitated samples were size-fractionated on tube gels according to the method of Swank and Munkres (1971). The tube gels were sliced (2 mm), the peptides were eluted, and the radioactivity was quantified by liquid scintillation counting (Dickerson et al., 1990). The top half of each gel, which contained no radioactivity (Marek and Mains, 1989), was discarded.

Recombinant plasmid construction and stable transfection studies. The $0.5 \mathrm{~kb}$ human pre-pro-NPY cDNA was inserted into the multiple cloning site of either pCIS.2CXXNH ( $\angle$ hou et al., 1993) or pSCEP la moditied version of pCEP4 (Invitrogen, San Diego, CA) in which the Epstein-Barr virus nuclear antigen and most of its origin of replication were deleted] vectors. The plasmids pCIS.NPY and pMt.neo-1 (Dickerson and Mains, 1990) were cotransfected into AtT-20 cells by lipofection. The recombinant lines were selected with G418 $(0.5 \mathrm{mg} / \mathrm{ml})$. GH3 cells were transfected with pSCEP.NPY by lipofection and selected with $200 \mathrm{U} / \mathrm{ml}$ hygromycin B (Sigma). The cell lines with the highest levels of expression were selected by immunostaining, Western analyses, and/or radioimmunoassay and were subcloned by limiting dilution as needed.

Recombinant adenovirus construction and infection studies. A $2.4 \mathrm{~kb}$ Not I fragment containing the entire rat PC1 coding sequence was ligated into pAdCMVI (Acsadi et al., 1994). For the construction of the PC2 antisense(as) transfer vector, pBS.rPC2 was digested with Sst1, made blunt with Klenow, and digested with Notl. This $1 \mathrm{~kb}$ fragment (nucleotides 242-1171) was ligated into pAdCMV1 digested with EcoRV and NotI. The recombinant adenoviruses were constructed essentially as described previously (Massie et al., 1995), except for the viral DNA used in the cotransfection, Ad5.CMV-LacZ DNA, which contains the Escherichia coli LacZ gene in the $\mathrm{E} 1$ region, providing a white-blue selection of recombinant adenovirus. The viral plaques were screened by Western and/or Southern blot. The positive plaques were amplified to achieve a viral stuck of $\sim 1 \times 10^{\times} \mathrm{pfu} / \mathrm{m}$. The viral preparations were purified through cesium chloride gradient as described previously (Massie et al., 1995). Infection of SCG primary cultures with serial dilutions of Ad5.CMV-LacZ was used to determine the minimum amount of virus necessary to infect a majority of the cell population. The titers of the other viral preparations were adjusted by optical density to the Ad5.CMV-LacZ value at $260 \mathrm{~nm}$. The cells were then inoculated with Ad5.CMV-LacZ, Ad5.PC1(s), or Ad5.PC2(as) in $0.5 \mathrm{ml}$ of CSFM for 24 hr. The next day the medium was replaced with fresh CSFM; 48-72 hr after infection, the cells were immunostained, extracted, or pulse-labeled, and the NPY-derived peptides were analyzed as described previously. 


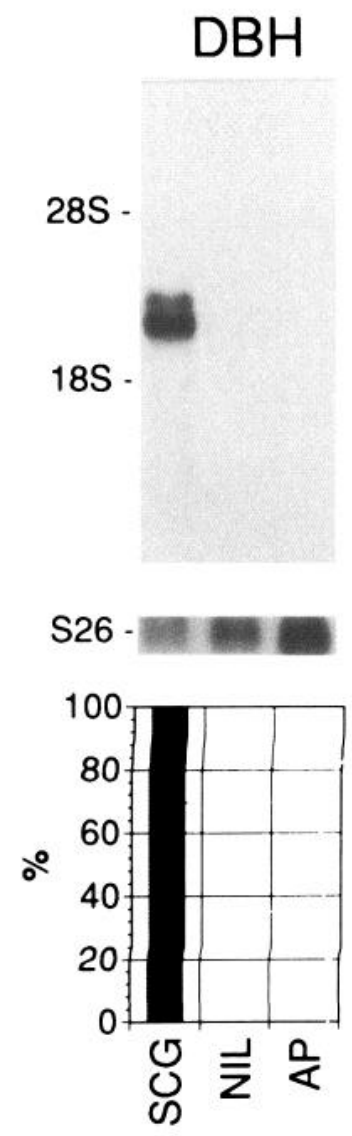

Furin

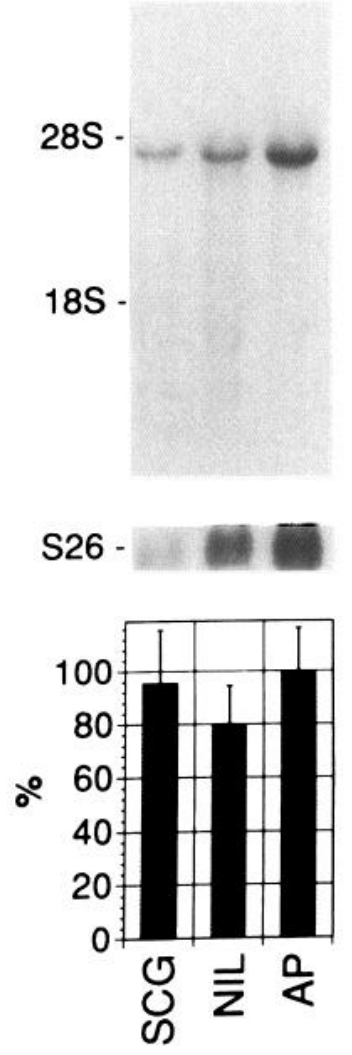

NPY

POMC

7B2

28S -

28S -

$28 \mathrm{~S}$

$18 S$ -

18S -

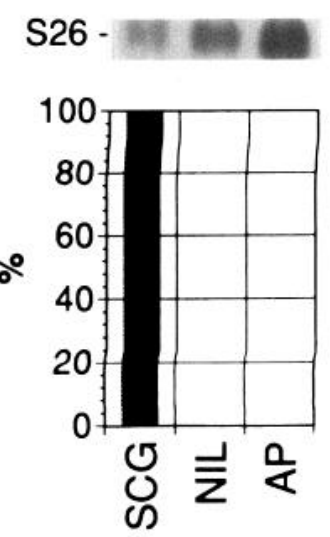

PACE4

28S -

$18 S$.

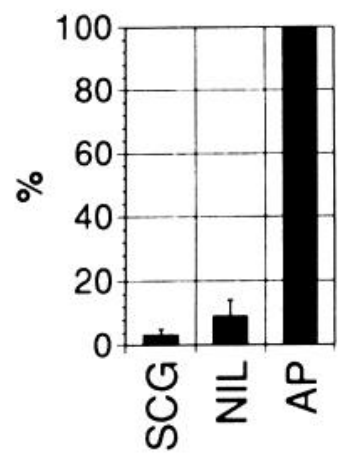

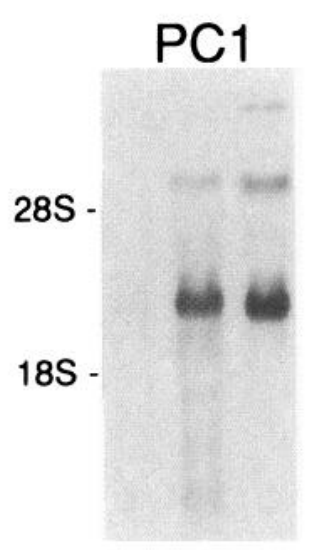

S26 -

S26 -

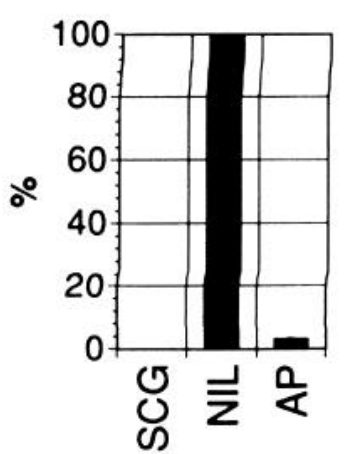

ஃ
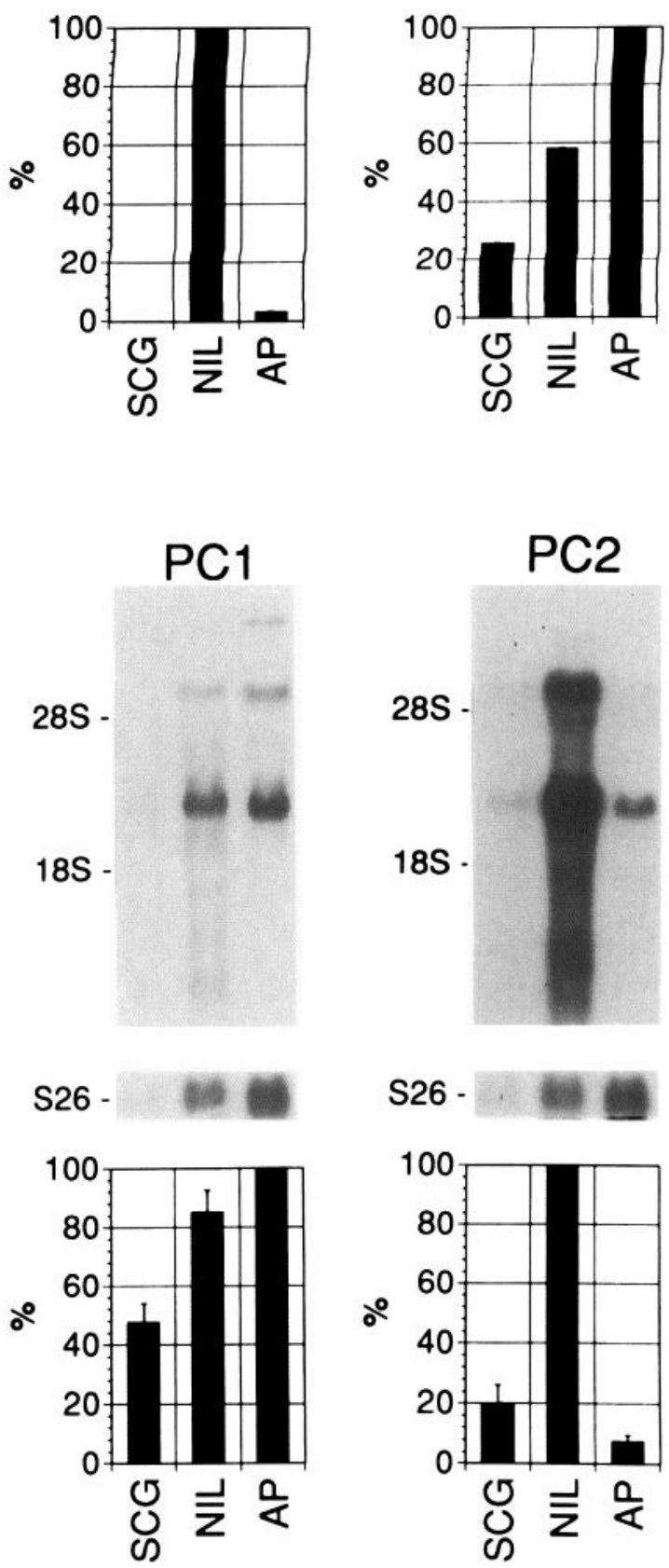

S26 -

28S -

18S .

PC2

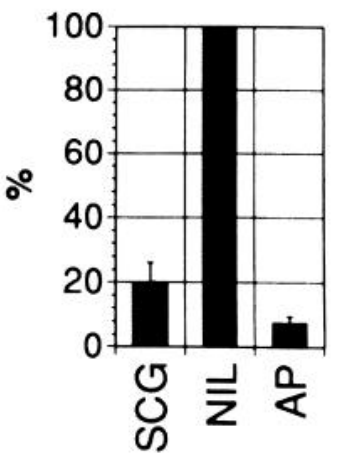



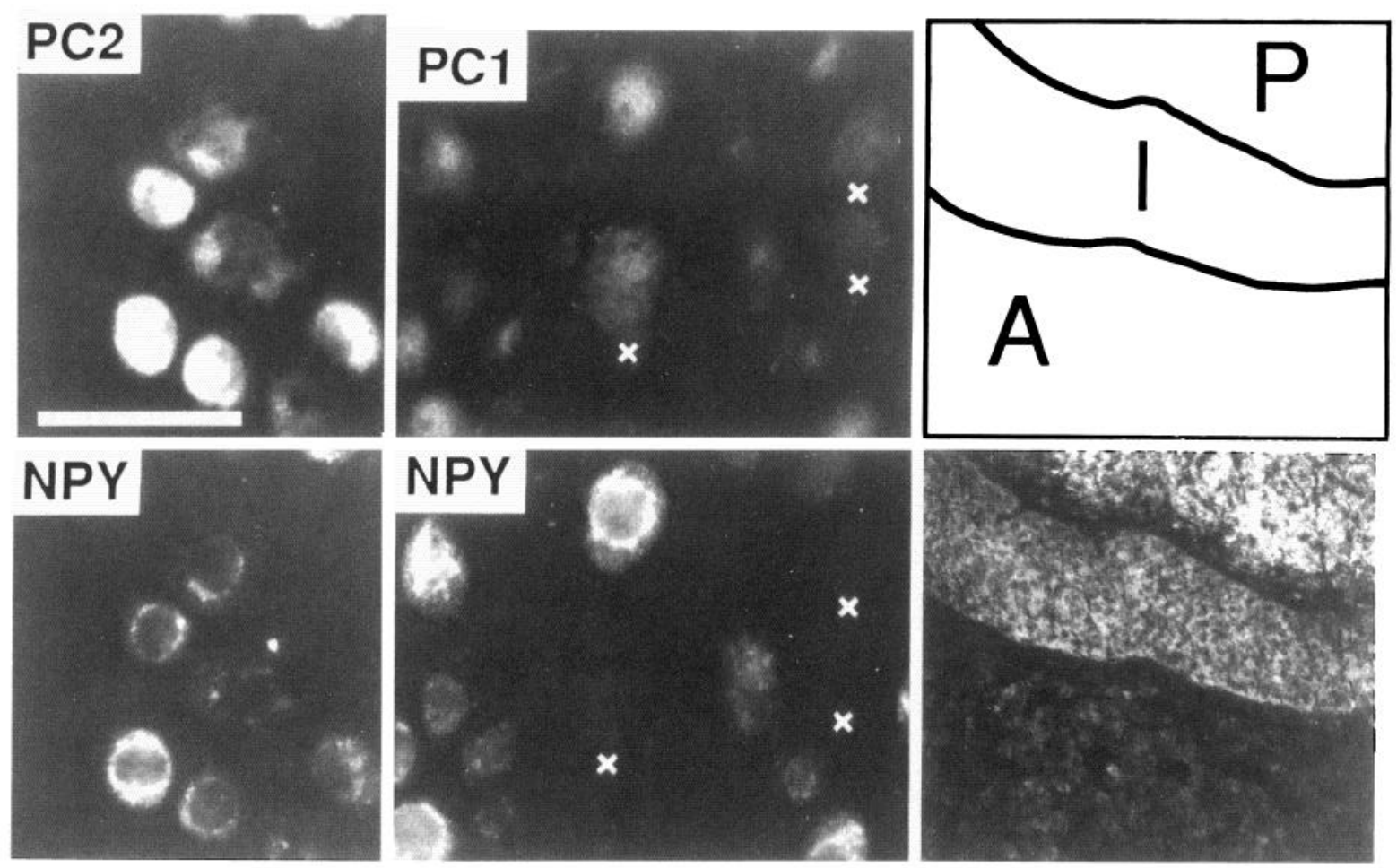

Figure 2. Colocalization of $N P Y$ with $P C 1$ and $P C 2$ by immunohistochemistry in SCG tissue. Guinea pig anti-NPY and rabbit anti-PC1 or -PC2 were visualized in sections of adult rat SCG. Scale bar, $100 \mu \mathrm{m}$. For comparison, staining of the adult rat pituitary for PC1 is shown at lower magnification $(A$, anterior pituitary; $I$, intermediate pituitary; $P$, posterior or neural pituitary).

\section{RESULTS}

\section{Convertase and large dense-core granule marker expression in SCG}

Northern blot analyses were used to investigate the expression of mRNAs for several different convertases, as well as several LDCV markers in the SCG from adult rats. The levels of expression found in the SCG were compared with the levels of expression in the anterior and intermediate lobes of the pituitary, two well characterized endocrine tissues specialized for the production, storage, and secretion of prohormones and their peptide products in LDCV (Mains and Eipper, 1990). Marker signals were normalized to the levels of S26, a ribosomal protein with a transcript present at similar levels in many tissues (Vincent et al., 1993). As expected, expression of dopamine $\beta$-hydroxylase and NPY mRNAs was limited to the SCG; these transcripts were absent from the pituitary tissues (Fig. 1). Conversely, POMC transcripts were detected only in pituitary (Fig. 1). The mRNA for the proprotein 7B2, thought to be a specific PC2 chaperone protein (Braks and Martens, 1994), was prevalent in all three tissues, and the level found in the SCG was fourfold lower than that found in the anterior pituitary (Paquet et al., 1994).

Similar amounts of furin mRNA were found in the three tissues examined, whereas PACE4 message could barely be detected in the SCG and intermediate lobe of the pituitary (Fig. 1). PC1 expression in the SCG was approximately half the level found in both pituitary tissues (Fig. 1). PC2 expression was about threefold more abundant in the SCG than in the anterior pituitary, but fivefold less than in the intermediate lobe of the pituitary (Fig. 1). Because the furin distribution is ubiquitous and its substrate specificity does not match the pro-NPY cleavage site, it was not considered a putative candidate processing enzyme. Because $\sim 60 \%$ of the neuronal population in the SCG expresses NPY (Jarvi et al., 1986), experiments aimed at localizing the convertases PC1 and PC2 with respect to NPY were carried out.

\section{Analysis of PC1 and PC2 steady-state localization in SCG}

Sections of ganglia from adult rats were double-immunostained for NPY and either PC1 or PC2. The results (Fig. 2) show a striking correspondence between the sites of NPY and PC2 expression; all of the PC2-positive neurons expressed NPY and vice versa. By contrast, expression of PC1 was much more widespread, with both NPY neurons and other neurons expressing PC1. The PC1 immunostaining was weak, and some staining was probably nonspecific, because staining was detected in the nucleus. It might be important for understanding pro-NPY processing that all NPY-positive neurons were also weakly positive for PC1. Using antisera raised against either a synthetic $\mathrm{PC} 1$ peptide or a bacterially expressed fragment of the $\mathrm{PC} 1$ protein, we have tried to optimize the immunodetection of $\mathrm{PC1}$ proteins. In all cases, the staining was close to background (Fig. 2), suggesting that the level of expression of PC1 was weak in adult SCG neurons. When we immunostained whole pituitary under the same conditions, the expected pattern of $\mathrm{PC} 1$ immunostaining was seen in all three $\leftarrow$

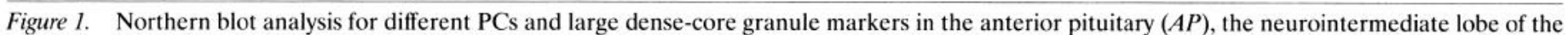

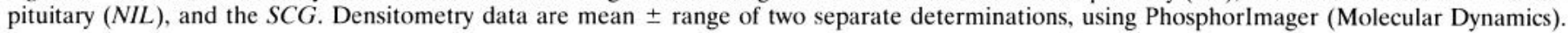



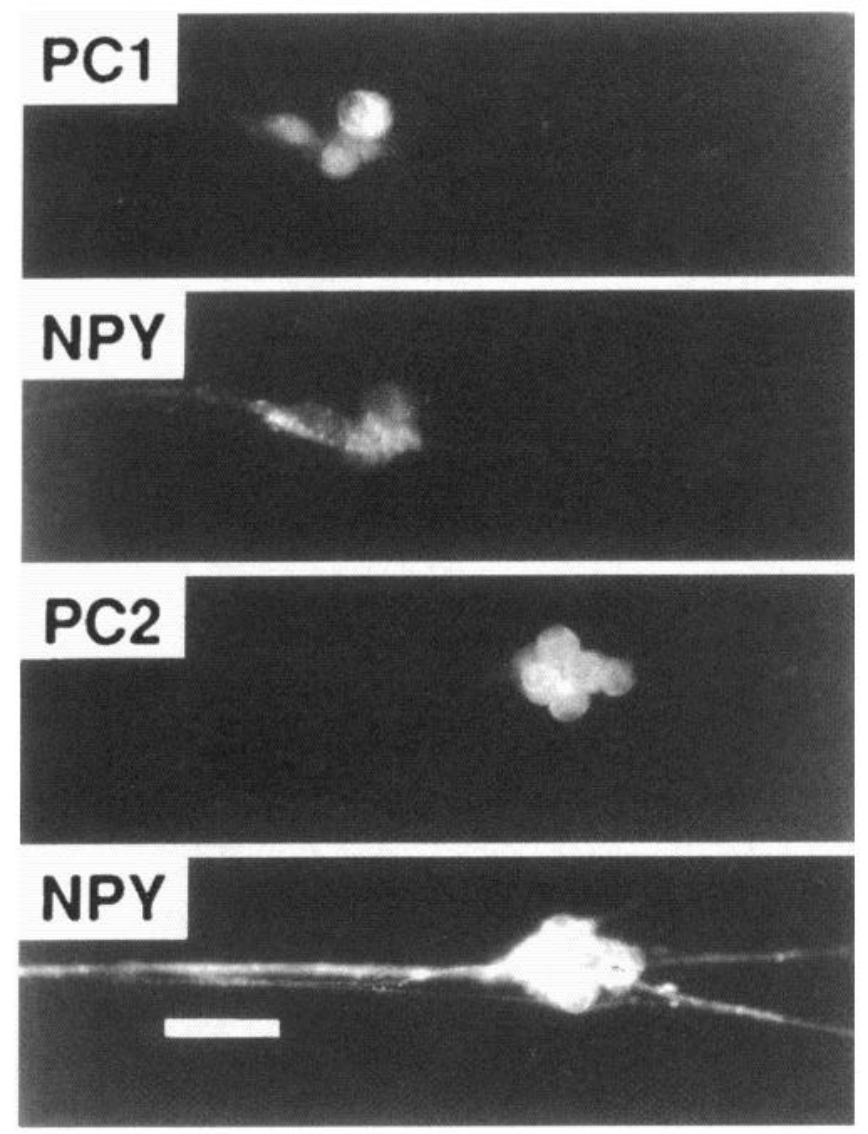

Figure 3. Distribution of $N P Y, P C 1$, and $P C 2$ in SCG primary cultures. Visualization as in Figure 2, using primary cultures. Scale bar, $100 \mu \mathrm{m}$.

lobes of the pituitary (Fig. 2) (Bloomquist et al., 1991; Day et al., 1992).

\section{Steady-state distribution of PC1 and PC2 in SCG primary cultures}

Primary cultures of SCG can be maintained without spinal or brain input or target cell contacts (Marek and Mains, 1989; Patterson and Nawa, 1993; Landis, 1994). Under these conditions, NPY synthesis increases 30 -fold between days 1 and 21 in culture to reach adult levels (Marek and Mains, 1989). To determine whether the expression of prohormone-processing enzymes in these cultured noradrenergic neurons was similar to the pattern observed in vivo, the expression of $\mathrm{PC} 1$ and $\mathrm{PC} 2$ in primary cultures was analyzed by indirect immunofluorescent staining. As in the live animal, all NPY-containing neurons also expressed PC2 (Fig. 3). Interestingly, the PC2 staining was concentrated in the cell bodies, and the processes were barely visible. NPY and PC1 were also found together in neurons, but the PC1 staining was found more in the processes than the PC2 staining was. In stably transfected neuroendocrine cells, the staining of PC2 is largely restricted to a perinuclear location, whereas $\mathrm{PC} 1$ accumulates in secretory granules found at the ends of cellular processes (Zhou et al., 1995).

\section{Localization of NPY compared with synaptic vesicle markers and markers of cell polarity in SCG primary cultures}

The steady-state localization of NPY was investigated by indirect immunofluorescent staining of SCG primary cultures. In SCG neurons, a diffuse NPY staining pattern was found in the cell bodies, whereas a punctate or vesicular staining pattern was revealed along the entire length of the axon (Fig. 4). The distribution of NPY in the neurons closely mirrored that of the vesicular markers synapsin and synaptophysin (Fig. 4). In culture, SCG neurons appropriately segregate a variety of marker proteins, as do cultured hippocampal neurons (Craig and Banker, 1994). One such marker, MAP-2, is found specifically in soma and dendrites. The distribution of both NPY and MAP-2 overlapped in the cell body (Fig. 4); no MAP-2 staining was observed colocalized with NPY along the axon.

\section{Kinetics of conversion of pro-NPY in different cell systems}

Because transfected pro-NPY is cleaved efficiently in cells that express PC1 or PC2 (Dickerson and Mains, 1990; Wulff et al., 1993) and SCG neurons expressing NPY have detectable levels of both PC1 and PC2, we sought ways to distinguish the actions of the two enzymes. Based on studies of POMC biosynthetic processing, $\mathrm{PC} 1$ is activated much earlier in the secretory pathway than PC2 (Zhou et al., 1993; Lindberg, 1994; Zhou and Mains, 1994). Removal of the PC1 prosegment occurs within a few minutes after its synthesis in the endoplasmic reticulum, whereas conversion of pro-PC2 to $\mathrm{PC} 2$ occurs in a post-Golgi compartment (Benjannet et al., 1993; Lindberg, 1994; Milgram and Mains, 1994; Zhou and Mains, 1994). Furthermore, in the case of POMC processing, cleavages catalyzed by $\mathrm{PC} 1$ precede those catalyzed by PC2 (Schnabel et al., 1989; Zhou et al., 1993). It was reasoned that the kinetics of processing of pro-NPY might provide a way to distinguish between the actions of PC1 and PC2. Cell lines expressing pro-NPY and $\mathrm{PC} 1$ or $\mathrm{PC} 2$ provided points of reference. AtT-20 cells express high levels of PC1 and negligible amounts of $\mathrm{PC} 2$, and $\mathrm{GH} 3$ cells express $\mathrm{PC} 2$ but no detectable PC1. Both cell lines were stably transfected with vectors encoding pro-NPY. The rates of pro-NPY synthesis and maturation were compared among the SCG primary cultures and transfected AtT-20 and GH3 cells. In all three cell systems, after $15 \mathrm{~min}$ of pulse labeling, all NPY immunoreactive material was recovered as an $8 \mathrm{kDa}$ molecule the size of pro-NPY (Fig. 5A) (not shown). In AtT-20 cells, half the pro-NPY was converted to mature NPY after $30 \mathrm{~min}$ of chase, and conversion was almost complete after $60 \mathrm{~min}$ of chase (Fig. $5 B$ ). In contrast to AtT-20 cells, the kinetics of processing of pro-NPY was more delayed in $\mathrm{GH} 3$ cells, with negligible conversion at 30 min, and only $50 \%$ conversion of pro-NPY after $60 \mathrm{~min}$ of chase (Fig. 5B). In SCG cultures, conversion of pro-NPY was negligible at $30 \mathrm{~min}$, significant $(40 \%)$ at $60 \mathrm{~min}$, and nearly complete at 120 min of chase. Thus, the kinetics of conversion of pro-NPY in the SCG primary cultures was very similar to the kinetics of pro-NPY conversion in GH3 cells (Fig. $5 B$ ). This result suggests that the most prevalent pro-NPY converting enzyme in SCG neurons has kinetic properties resembling those of $\mathrm{PC} 2$, the predominant convertase in $\mathrm{GH} 3$ cells.

Another tool used to distinguish cleavages catalyzed by PC2 and $\mathrm{PCl}$ is the $20^{\circ} \mathrm{C}$ temperature block (Griffiths et al., 1985; Griffiths and Simons, 1986; Arvan and Castle, 1992; Rothman and Orci, 1992). In AtT-20 cells, PC1 catalyzes cleavages at a reduced rate at $20^{\circ} \mathrm{C}$ (Milgram and Mains, 1994). In transfected AtT-20 cells expressing PC2, the additional PC2-dependent cleavages are largely eliminated by the $20^{\circ} \mathrm{C}$ temperature block (Zhou and Mains, 1994). Primary SCG cultures, AtT-20 cells, and GH3 cells expressing NPY were pulse-labeled at $37^{\circ} \mathrm{C}$, then chased at 37 or $20^{\circ} \mathrm{C}$ for 60 or $120 \mathrm{~min}$. In Figure 6 , data are summarized showing that pro-NPY cleavage was markedly retarded by the $20^{\circ} \mathrm{C}$ chase 

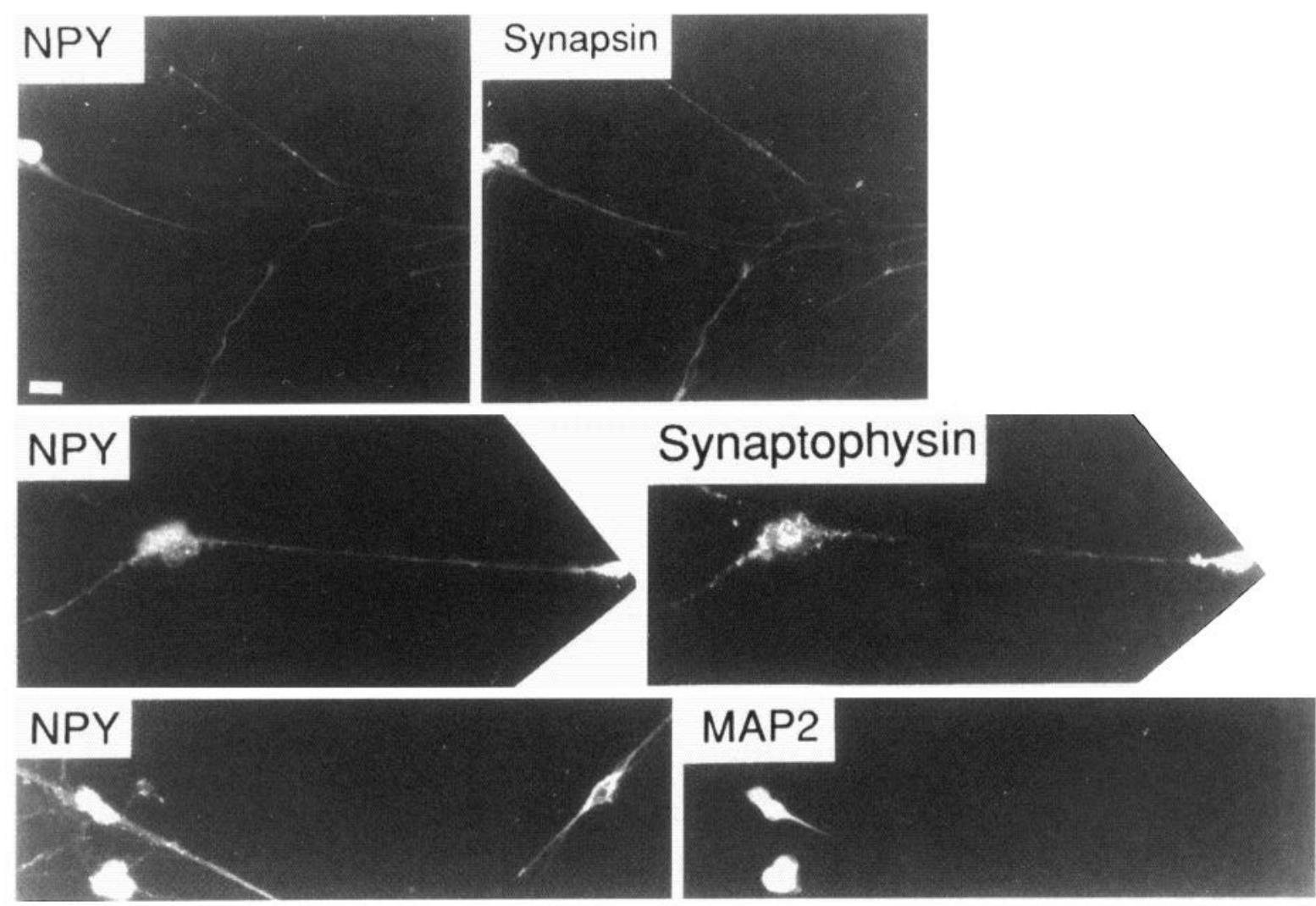

Figure 4. Axonal and dendritic distributions of NPY and marker proteins in SCG primary cultures. The cultures were immunostained simultaneously with rabbit anti-NPY (NPY) serum and either anti-MAP-2 (MAP2), anti-synaptophysin (synaptophysin) or anti-synapsin (synapsin) monoclonal antibodies. Note the NPY-positive but MAP-2-negative terminal arborizations near the cells at the left and at the bottom right of the figure. Scale bar, $100 \mu \mathrm{m}$.

in SCG neurons and GH3 cells. In contrast, in AtT-20 cells the cleavage of pro-NPY continued at a reduced rate and was substantially completed in $2 \mathrm{hr}$ at $20^{\circ} \mathrm{C}$. Control experiments showed negligible secretion from all three cell types at $20^{\circ} \mathrm{C}$ (data not shown). Although pro-NPY conversion was substantially retarded by a $20^{\circ} \mathrm{C}$ block in SCG neurons, it was much more efficient than in GH3 cells in which cleavage of pro-NPY was totally blocked. This result suggests that the contribution of PC1 to pro-NPY conversion is minor in SCG neurons at $37^{\circ} \mathrm{C}$ but that the accumulation of proteins in the trans-Golgi network (TGN) generated by a $20^{\circ} \mathrm{C}$ block favors catalysis by a PC1-like enzyme.

\section{Modulation of PC1 and PC2 expression in SCG primary cultures}

To assess further the function of PC1 and PC2 in pro-NPY processing in SCG neurons, recombinant adenoviruses encoding $\mathrm{PC} 1$ and antisense PC2 were constructed. Control studies using a recombinant adenovirus encoding the $E$. coli LacZ gene indicated that $>95 \%$ of the neuronal population could be infected under our experimental conditions (Fig. 7A). When PC1 was overexpressed in SCG primary cultures, immunoreactive PC1 was found as two major bands corresponding to the active $87 \mathrm{kDa}$ PC1 and the carboxy-truncated $66 \mathrm{kDa}$ form (Fig. $7 B$ ). Under our experimental conditions, overexpression of $\mathrm{PC} 1$ in the SCG primary culture was comparable to the steady-state level of PC1 expression in the anterior pituitary and substantially above the endogenous expression level (Fig. $7 B$ ). After infection of SCG primary cultures with the PC1 virus, the rate of pro-NPY processing was increased to a rate comparable with that seen in pro-NPY-transfected AtT-20 cells (Fig. $7 C$; compare with Fig. $5 B$ ). After $60 \mathrm{~min}$ of chase, $74 \%$ of the pro-NPY labeled during a 15 min pulse was already converted to its mature form (Fig. 7C).

SCG extracts contain a low but detectable amount of PC2 protein (Fig. 8), unlike the situation for PC1 (Fig. 7B). Thus, to assess the role of endogenous $\mathrm{PC} 2$ in pro-NPY processing in sympathetic neurons, an antisense RNA to $\mathrm{PC} 2$ was introduced into SCG primary cultures with an adenoviral vector. Because the expression of $\mathrm{PC} 2$ was low, immunocytochemistry was used to examine the effects of the antisense adenoviral vector on PC2 expression. In the presence of the antisense RNA to PC2, decreased staining intensity for PC2 was observed in a subset of the NPY neurons (Fig. 9A). This decreased staining intensity correlated with a decrease in the conversion efficiency of pro-NPY into NPY (Fig. 9B). The extent of processing of pro-NPY was slowed significantly over both a $1 \mathrm{hr}$ and a $2 \mathrm{hr}$ chase period (Fig. 9B). After 1 or $2 \mathrm{hr}$ chase incubations, the ratio of pro-NPY to mature NPY in the anti-PC2 cells was increased $138 \pm 13 \%$ (mean \pm SEM; $n=3$ ) compared with the LacZ- or mock-infected cells.

\section{DISCUSSION}

One of the major problems associated with the study of neuropeptide synthesis and processing in primary neurons is that the neurons often may not produce sufficient material for biochemical analysis. As an alternative approach, immortalization of cell lines after retroviral oncogene transduction or of neural cell lines such as PC12 seemed very promising. Unfortunately, these neuronal cell lines often do not segregate dendritic versus axonal markers, and it seems that these cell lines do not undergo complete maturation, remaining instead at an early stage of differentiation 

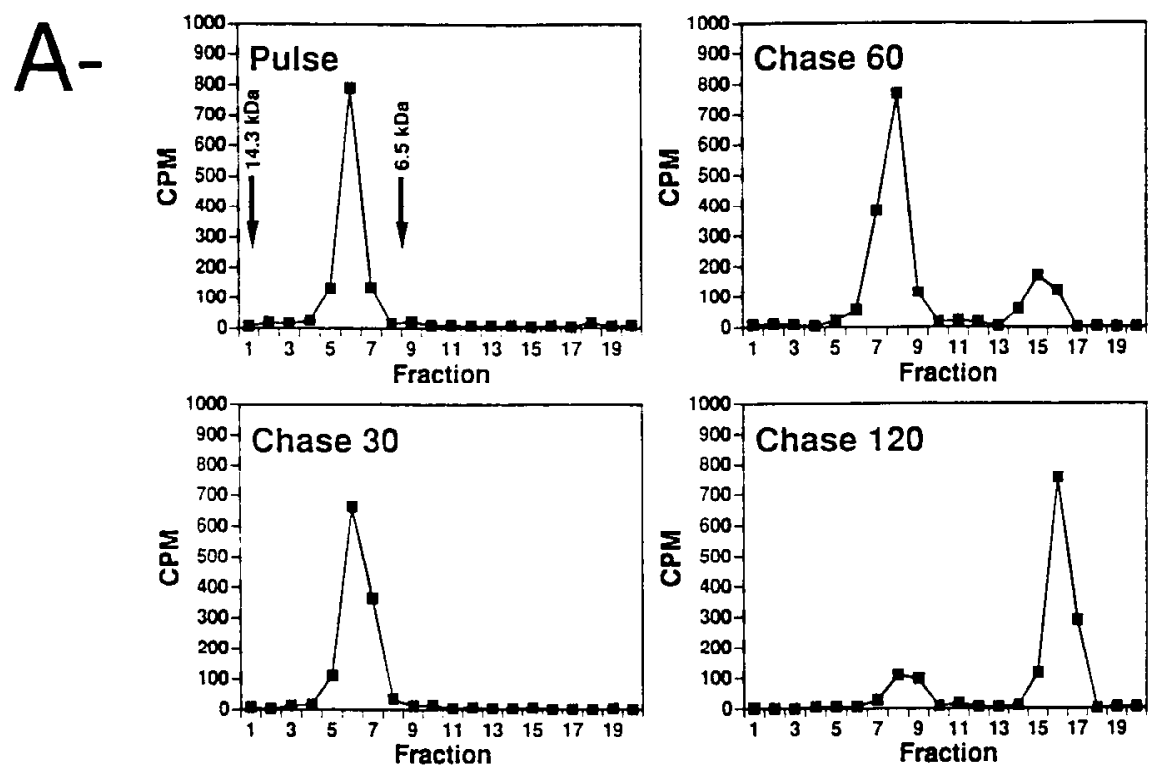

Figure 5. Kinetics of conversion of pro-NPY in SCG primary cultures and transfected neuroendocrine cell lines. SCG cells were grown for at least 2 weeks in culture to allow maximum expression of NPY (Marck and Mains, 1989). A, SCG cells were pulse-labeled for $15 \mathrm{~min}$ with ${ }^{35} \mathrm{~S}-\mathrm{Met} / \mathrm{Cys}$ and chased as indicated. Identical experiments were carricd out using AtT-20/NPY and GH3/NPY cells (not shown). $B$, The kinetics of conversion of proNPY (O, ProNPY; $\bullet$, NPY) in SCG primary cultures was compared with the kinetics of conversion of pro-NPY in transfected AtT-20 ( $\mathbf{\Delta}$ ) and GH3 (ם) cells (, $\mathrm{SCG})$. The results are the average \pm $\mathrm{SD}$ of two to four independent experiments.
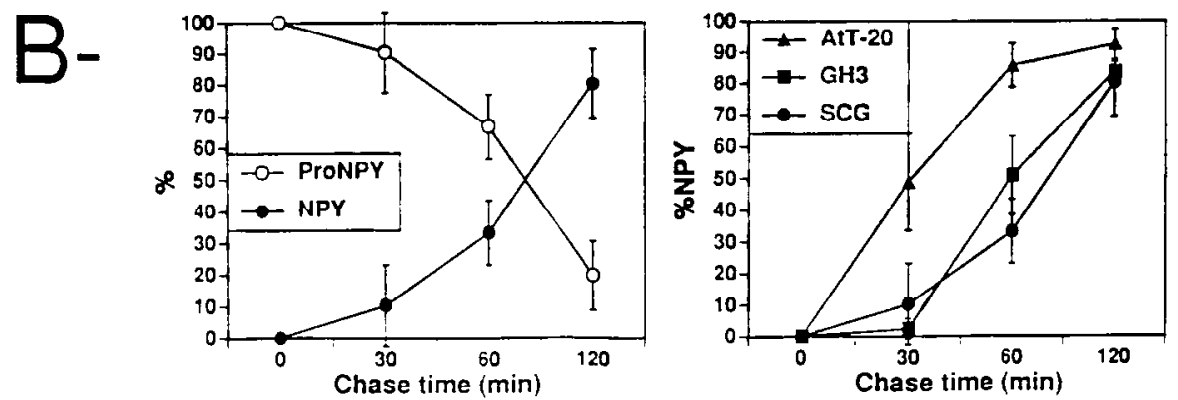

(Greene et al., 1991; Eves et al., 1992). Thus, primary cultures offer major advantages for biochemical and immunochemical analyses of neuronal function.

One of the early criteria for the identification of a putative PC was that "the participation in prohormone cleavage requires demonstration that inhibition, inactivation, or mutation of the enzyme prevents cleavage in the intact cell" (Docherty and Steiner, 1982). So far, such strong evidence has been obtained for endoproteases in only two cases, namely for a role of $\mathrm{PC} 1$ in POMC processing

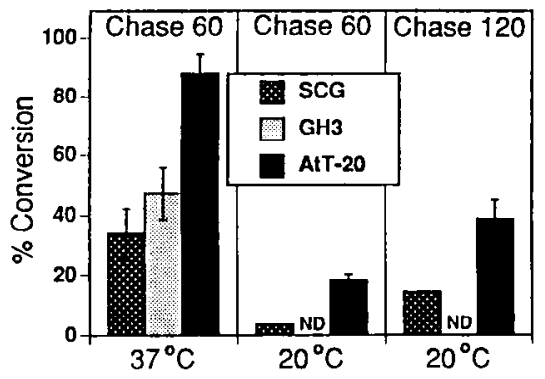

Figure 6. Effect of a $20^{\circ} \mathrm{C}$ temperature block on pro-NPY processing. The conversion of pro-NPY to NPY in SCG (hatched bars) primary cultures and stably transfected AtT-20 (hlack hars) and GH3 (shaded hars) cells were compared at 37 and at $20^{\circ} \mathrm{C}$ (mean \pm SD of 2 or 3 experiments with each cell type; $N D$, not detectable).
(Bloomquist et al., 1991) and of PC2 in the activation of proglucagon in pancreatic $\alpha$-cells (Rouillé et al., 1994).

\section{Comparative kinetics argues that PC2 is the physiological pro-NPY-cleaving enzyme}

In this study, we examined the proteolytic processing of pro-NPY in sympathetic neurons derived from SCG. Northern blot demonstrated that these neurons expressed both of the neuroendocrinespecific PCs, PC1 and PC2. By immunostaining, we demonstrated that PC2 expression was tightly linked to the NPYergic phenotype. Furthermore, PC2 mRNA was threefold morc abundant in SCG than in the anterior pituitary, emphasizing the importance of PC2 in SCG function. By Northern blot, PC1 mRNA was significantly lower than in the anterior pituitary, and $\mathrm{PCl}$ proteins were not detectable in SCG extracts by Western blot. A low level of staining for PC1 was detected in NPY neurons and in some additional neurons in the ganglion. By using two model endocrine cell lines, one expressing primarily PCl (AtT-20) and the other expressing mainly $\mathrm{PC} 2(\mathrm{GH} 3)$, we demonstrated that the kinetics of conversion of pro-NPY in SCG cultures was similar to the kinetics of conversion of pro-NPY in transfected GH3 cells. In SCG primary cultures and GH3 cells, there was a lag time of $\sim 30$ min, during which very little maturation of pro-NPY occurred. This probably represents the amount of time necessary for the pro-NPY molecules to reach the processing compartment. By 

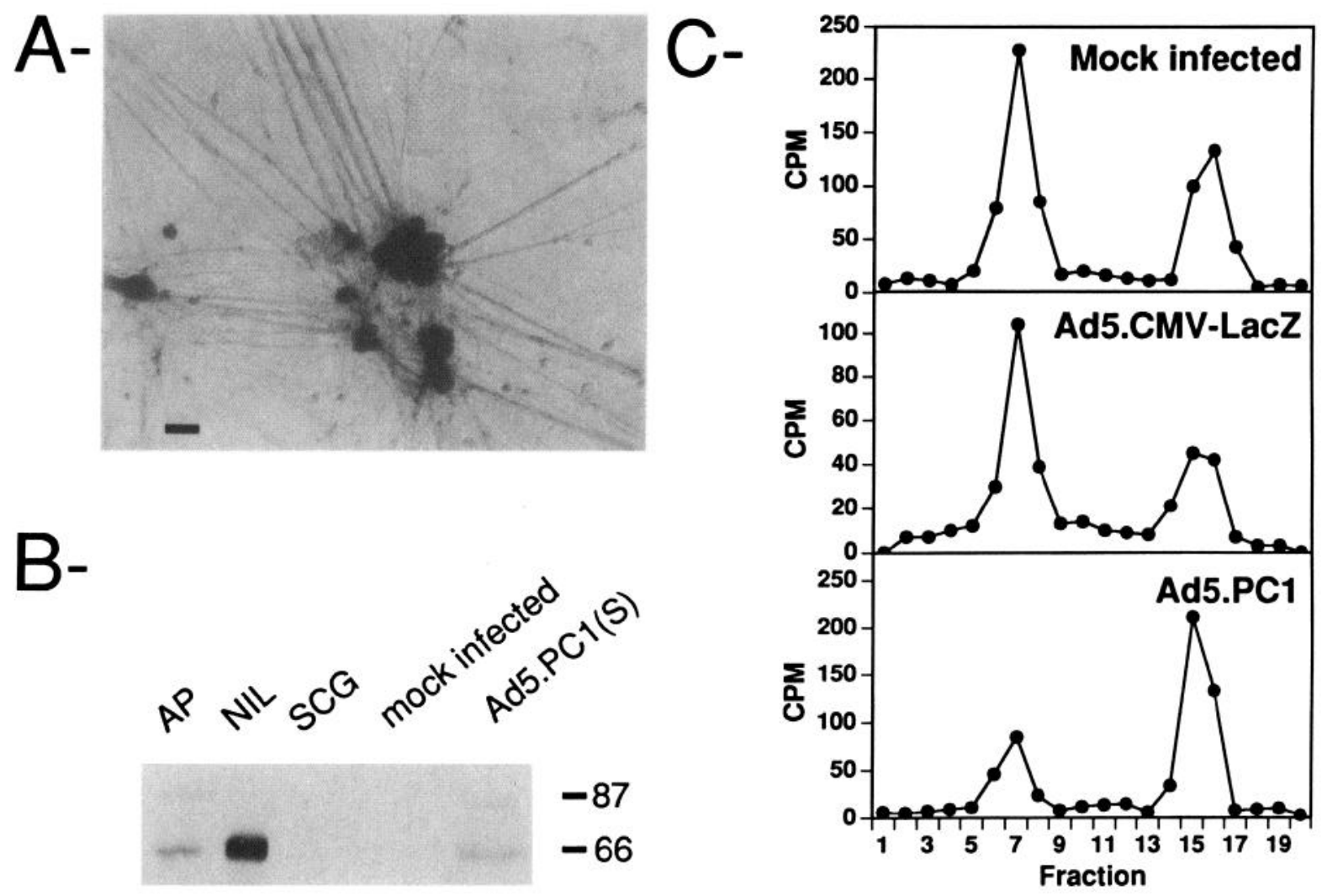

Figure 7. Increasing the level of PC1 in SCG neurons increases the rate of pro-NPY cleavage. $A$, The capacity of adenovirus to infect SCG neurons was evaluated by infection with Ad5.CMV-LacZ. Scale bar, $100 \mu \mathrm{m}$. B. Tissue extracts were fractionated by SDS-PAGE on a $10 \%$ acrylamide gel, and Western analysis was used to compare PC1 in mock infected or $A d 5 . P C 1(S)$-infected SCG cultures, anterior pituitary $(A P)$, the neurointermediate lobe of the pituitary $(N I L)$, or $S C G$; all samples contained $50 \mu \mathrm{g}$ of total protein. $C$, The kinetics of conversion of pro-NPY in SCG primary cultures was analyzed after infection with the recombinant PC1 adenovirus and compared with Mock infected and Ad5.CMV-LacZ virus-infected cultures (1 hr chase). Similar results were obtained in three similar experiments.

comparison, half of pro-NPY was already converted to NPY after $30 \mathrm{~min}$ of chase in AtT-20 cells. These results indicate that PC1 acts earlier than PC2 in the secretory pathway of endocrine cells and suggest that the neuronal pro-NPY processing enzyme has some properties of PC2. Although unlikely, this time course could also be explained by activation of PC1 in a post-Golgi compartment in sympathetic neurons.

Incubation of cells at $20^{\circ} \mathrm{C}$ is known to block the exit of proteins from the TGN (Griffiths et al., 1985; Griffiths and Simons, 1986; Arvan and Castle, 1992; Milgram and Mains, 1994). In AtT-20 cells, pro-NPY processing was slowed but proceeded to $40 \%$ in 2 hr at $20^{\circ} \mathrm{C}$, whereas in $\mathrm{GH} 3$ cells the $20^{\circ} \mathrm{C}$ temperature block completely prevented the processing of pro-NPY. This is in agreement with Xu and Shields (1994), who found that the processing

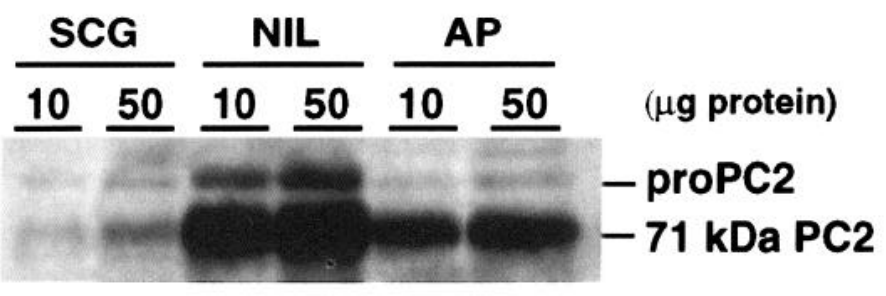

Figure 8. SCG extracts contain a low level of PC2 protein. Extracts (10 and $50 \mu \mathrm{g}$ of protein) of $S C G$, neurointermediate pituitary $(N I L)$, and anterior pituitary $(A P)$ were analyzed as in Figure $7 B$, using $\mathrm{PC} 2$ antiserum. of prosomatostatin in transfected $\mathrm{GH} 3$ cells was stopped by a $20^{\circ} \mathrm{C}$ incubation. The proteolytic processing of pro-NPY in SCG primary cultures was not entirely abolished by the $20^{\circ} \mathrm{C}$ incubation but was slowed substantially more than pro-NPY processing in AtT-20 cells. Because NPY-producing neurons have both PC1 and $\mathrm{PC} 2$, it is possible that accumulation of proteins in the TGN by a $20^{\circ} \mathrm{C}$ block allows the interaction of a $\mathrm{PC} 1$-like enzyme and pro-NPY. This suggests that the intracellular organelle in which pro-NPY conversion normally takes place is distal to the TGN, probably the immature vesicles. Taken together, these results suggest that PC2 is more likely to be the pro-NPY processing enzyme under physiological conditions.

\section{Use of adenovirus to manipulate the SCG cultures provides additional evidence for the physiological role of PC2 in pro-NPY processing}

The efficient delivery of foreign genes into postmitotic cells is becoming very important for studies of nervous system functions. Helper-independent-defective adenoviral vectors were constructed by deleting the E1 and E3 regions of the viral genome (Gluzman et al., 1982; Brett et al., 1993). These viruses are incompetent to replicate in all mammalian cells except cell lines such as hEK-293, which constitutively express the E1 proteins (Graham et al., 1977; Gluzman et al., 1982; Brett et al., 1993). To modulate the expression of different processing enzymes possibly involved in pro-NPY activation, we took advantage of the fact that adenovirus has the ability to transfer genetic material into neuro- 

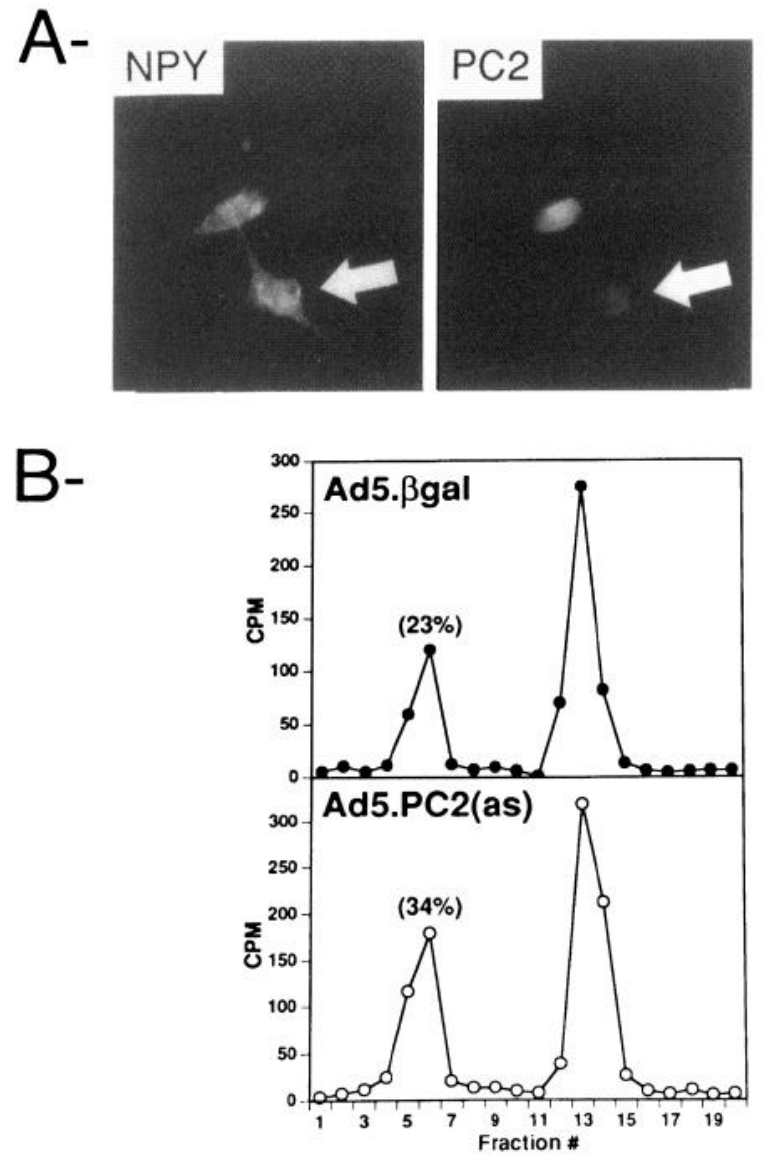

Figure 9. Expression of PC2 antisense RNA in SCG neurons decreases the rate of pro-NPY cleavage. $A, \mathrm{SCG}$ cultures infected with adenovirus encoding antisense RNA for rat $\mathrm{PC} 2$ were immunostained simultaneously for PC2 and NPY as in Figure 3. B, The kinetics of conversion of pro-NPY in SCG primary culture was analyzed after infection with the recombinant anti-PC2 adenovirus and compared with mock-infected and Ad5.CMVLacZ virus-infected cultures after a $2 \mathrm{hr}$ chase incubation. Similar results were obtained in three similar experiments.

nal cells with negligible apparent toxic effects (Le Gal La Salle et al., 1993).

The size distribution of PC1 molecules in the Ad5.PC1-infected SCG primary cultures was similar to that in the anterior pituitary. At steady state in the neurointermediate lobe of the pituitary, most of the PC1 immunoreactive material was found as the 66 $\mathrm{kDa}$ form. The overexpression of $\mathrm{PCl}$ in neurons resulted in fast and efficient processing of pro-NPY, suggesting that the subcellular environment is compatible with an early action of $\mathrm{PC} 1$ within the secretory pathway. This suggests that if enough $\mathrm{PC} 1$ enzyme were produced endogenously in SCG neurons, the kinetics of conversion of pro-NPY would be faster and the low endogenous supply of PC1 was at least partially rate-limiting for the conversion of pro-NPY to NPY.

Although adenovirus can be used at multiplicity of infections (MOIs) in excess of 1000 without any deleterious effect in some cell lines (Davidson and Hassell, 1987), other cells cannot tolerate MOIs exceeding 100-200 without toxic effect (our unpublished observations). Such was the case with the SCG neurons, which showed a dramatic decrease in total protein synthesis when infected at higher MOIs. It was not possible to increase the expression of the PC2 antisense construct further by increasing the MOIs. Nevertheless, when the expression of an antisense RNA to
PC2 was induced in SCG primary cultures by a recombinant adenovirus, a moderate but specific decrease in the endogenous activity of PC2 toward pro-NPY was observed, despite marked effects on the level of PC2 in only a subset of neurons. Because the turnover of PC2 messenger RNA is relatively rapid (Bhat et al., 1993), it is presumably important to achieve an excess of antisense RNA over endogenous PC2 mRNA to have an efficient effect on PC2 synthesis. As in many other antisense studies (Murray and Crockett, 1992; Mains, 1995), the ideal goal of abolition of PC2 action was not achieved, but a significant diminution in the rate of pro-NPY processing was still achieved. Taken together, these results provide strong evidence for $\mathrm{PC} 2$ as the physiologically dominant pro-NPY-converting enzyme.

The capacity of PC1 to cleave pro-NPY efficiently when overexpressed in SCG neurons might be of physiological importance. Indeed, SCG postmitotic neurons alter their neurotransmitter phenotype when grown in the presence of conditioned medium; the noradrenergic neurons can be induced to become cholinergic (Landis, 1994). In addition to the cholinergic phenotype induction, expression of somatostatin, VIP, SP, and enkephalin-derived peptides is also induced by conditioned media (Nawa and Sah, 1990). Although there is a major phenotype change from noradrenergic to cholinergic, NPY is maintained under these conditions (Marek and Mains, 1989; Patterson and Nawa, 1993). These results suggest that the expression of neuropeptide and neurotransmitter is not necessarily coregulated. But in the long run, the expression of processing enzymes must be coordinated with the biogenesis of active peptides (as in the intermediate lobe of the pituitary; Bloomquist et al., 1991).

\section{REFERENCES}

Acsadi G, Jani A, Massie B, Simoneau M, Blaschuk K, Karpati G (1994) A differential efficiency of adenovirus-mediated in vivo gene transfer into skeletal muscle cells of different maturity. Hum Mol Genet 3:579-584.

Arvan P, Castle D (1992) Protein sorting and secretion granule formation in regulated secretory cells. Trends Cell Biol 2:327-331.

Benjannet S, Rondeau N, Day R, Chrétien M, Seidah NG (1991) PC1 and $\mathrm{PC} 2$ are proprotein convertases capable of cleaving proopiomelanocortin at distinct pairs of basic residues. Proc Natl Acad Sci USA 88:3564-3568.

Benjannet S, Rondeau N, Paquet L, Boudreault A, Lazure C, Chrétien M, Seidah NG (1993) Comparative biosynthesis, covalent post-translational modifications and efficiency of prosegment cleavage of the prohormone convertases PC1 and PC2: glycosylation, sulphation and identification of the intracellular site of prosegment cleavage of $\mathrm{PC} 1$ and $\mathrm{PC} 2$. Biochem $\mathrm{J}$ 294:735-743.

Bhat RV, Tausk FA, Baraban JM, Mains RE, Eipper BA (1993) Rapid increases in peptide processing enzyme expression in hippocampal neurons. J Neurochem 61:1315-1322.

Bloomquist BT, Mains RE (1993) The eucaryotic prohormoneprocessing endoproteases. Cell Physiol Biochem 3:197-212.

Bloomquist BT, Eipper BA, Mains RE (1991) Prohormone converting enzymes: regulation and evaluation of function using antisense RNA. Mol Endocrinol 5:2014-2024.

Braks JA, Martens GJ (1994) 7B2 is a neuroendocrine chaperone that transiently interacts with prohormone convertase PC2 in the secretory pathway. Cell 78:263-273.

Brett AJ, Prevec L, Graham F (1993) Packaging capacity and stability of human adenovirus type 5 vectors. J Virol 67:5911-5921.

Chomczynski P, Sacchi N (1987) Single-step method of RNA isolation by acid guanidinium thiocyanate-phenol-chloroform extraction. Anal Biochem 162:156-159.

Craig AM, Banker G (1994) Neuronal polarity. Annu Rev Neurosci 17:267-310.

Davidson D, Hassell JA (1987) Overproduction of polyomavirus middle $\mathrm{T}$ antigen in mammalian cells through the use of an adenovirus vector. J Virol 61:1226-1239. 
Day R, Schafer MKH, Watson SI, Chretien M, Seidah NG (199?) Distribution and regulation of the prohormone convertases $\mathrm{PC} 1$ and $\mathrm{PC} 2$ in the rat pituitary. Mol Endocrinol 6:485-497.

Dickerson IM, Mains RE (1900) Cell-type specific posttranslational processing of peptides by different pituitary cell lines. Endocrinology 127:133-140.

Docherty K, Steiner DF (1982) Post-translational proteolysis in polypeptide hormone biosynthesis. Annu Rev Physiol 44:625-638.

Dumont Y, Martel J, Fournier A, St Pierre S, Quirion R (1992) Neuropeptide $\mathrm{Y}$ and neuropeptide $\mathrm{Y}$ receptor subtypes in brain and peripheral tissues. Prog Neurobiol 38:125-167.

Egger C, Kirchmair R, Hoguc-Angeletti R, Fischer-Colbrie R, Winkler H (1993) Different degrees of processing of secretogranin II in large dense core vesicles of bovine adrenal medulla and sympathetic axons correlate with their content of soluble PC1 and PC2. Neurosci Lett 159:199-201.

Eves EM, Tucker MS, Roback JD, Downen M, Rosner MR, Wainer BH (1992) Immortal rat hippocampal cell lines exhibit neuronal and glial lineages and neurotrophin gene expression. Proc Natl Acad Sci USA $89: 4373-4377$

Gluzman Y, Reichl H, Solnick D (1982) Helper-free adenovirus type 5 vectors. In: Eucaryotic viral vectors (Gluzman $Y$, ed), pp 187-192. New York: Cold Spring Harbor Laboratory.

Gotoh B, Ohnishi Y, Inocencio NM, Esaki E, Nakayama K, Barr PJ, Thomas G, Nagai Y (1992) Mammalian subtilisin-related proteinases in cleavage activation of the paramyxovirus fusion glycoprotein: superiority of furin/PACE to PC2 or PC1/PC3. J Virol 66:6391-6397.

Graham F, Smiley JR, Russell WC, Nairn R (1977) Characteristics of a human cell line transformed by DNA from human adenovirus type 5 . J Gen Virol 36:59-72

Greene LA, Sobeih MM, Teng KK (1991) Methodologies for the culture and experimental use of the PC12 rat pheochromocytoma cell line. In: Culturing nerve cells (Banker G, Goslin K, eds), pp 206-216. Cambridge, MIT

Griffiths G, Simons K (1986) The trans-Golgi network: sorting at the exit site of the Golgi complex. Science 234:438-443.

Griffiths G, Pfeiffer S, Simons K, Matlin K (1985) Exit of newly synthesized membrane proteins from the trans cisternae of the Golgi complex to the plasma membrane. J Cell Biol 101:949-964.

Higgins D, Waxman A, Banker G (1988) The distribution of microtubulc-associated protein 2 changes when dendritic growth is induced in rat sympathetic neurons in vitro. Ncuroscience 24:583-592.

Jarvi R, Helen P, Huikko MP, Hernoven A (1986) NPY-like immunoreactivity in rat sympathetic neurons and small granule-containing cells. Neurosei Let1 67:223-227.

Landis SC (1978) Growth concs of cultured sympathetic ncurons contain adrenergic vesicles. J Cell Biol 78:R8-R14.

Landis SC (1994) Development of sympathetic neurons: neurotransmitter plasticity and differentiation factors. Prog Brain Res 100:19-23.

Le Gal La Salle G, Robert JJ, Berrard S, Ridoux V, Stratford-Perricaudet LD, Perricaudet M, Mallet J (1993) An adenovirus vector for gene transfer into neurons and glia in the brain. Science 259:988-990.

Lindberg I (1991) The new eukaryotic precursor processing proteinases. Mol Endocrinol 5:1361-1365.

Lindberg I (1994) Evidence for cleavage of the PC1/PC3 pro-segment in the endoplasmic reticulum. Mol Cell Neurosci 5:263-268.

Mains RE (1995) Use of antisense RNA to block peptide processing enzyme expression. Methods Neurosci 23:109-121.

Mains RE, Eipper BA (1990) The tissue-specific processing of proACTIV/endorphin. Trends Endocrinol Mctah 1:388-394.

Marek KL, Mains RE (1989) Biosynthesis, development, and regulation of neuropeptide $\mathrm{Y}$ in superior cervical ganglion culture. J Neurochem 52:1807-1816.

Marek KL. Mains RE (1990) Differential regulation of NPY and catecholamine production in SCG cultures. Mol Cell Neurosci 1:262-269.

Massie B, Dionne J, Lamarche N, Fleurent J, Langelier Y (1995) Improved adenovirus vector provides herpes simplex ribonucleotide reductase R1 and R2 subunits very efficiently. Bio/technology 13:6012-608.

May V. Brandenburg CA, Braas KM (1995) Differential regulation of sympathetic neuron neuropeptide $Y$ and catecholamine content and secretion. I Neurosci 15:4580-4591.
Milgram SI., Mains RF (1994) Differential effects of temperature blockade on the proteolytic processing of three secretory granule-associated proteins. J Cell Sci 107:737-745.

Muray JAH, Crockett N (1992) Antisense lechniques: an overview. In: Antisense RNA and DNA (Murray JAH, ed), pp 1-49. New York: Wiley.

Nawa H, Sah DWY (1990) Different biological activities in conditioned media control the expression of a varicty of neuropeptides in cultured sympathetic neurons. Neuron 4:279-287.

Paquet I., Bergeron F, Boudreault A, Seidah NG. Chretien M, Mhikay M. Lazure C (1994) The neuroendocrine precursor 7B2 is a sulfated protein proteolytically processed by a ubiquitous furin-like convertase. J Biol Chem 269:19279-19285.

Patterson PH, Nawa H (1993) Neuronal differentiation factors/cytokines and synaptic plasticity. Neuron [Suppl] 10:123-127.

Rothman JE, Orci L (1992) Molecular dissection of the secretory pathway. Nature 355:409-415.

Rouillé Y. Westermark G, Martin SK, Steiner DF (1994) Proglucagon is processed to glucagon hy prohormone convertase PC2 in $\alpha \mathrm{TC}$ I- 6 cells. Proc Natl Acad Sci USA 91:3242-3246.

Scheller RII (1995) Membrane trafficking in the presynaptic nerve terminal. Neuron 14:893-897.

Schnabel E, Mains RE, Farquhar MG (1989) Proteolytic processing of pro-ACTH/endorphin begins in the Golgi complex of pituitary corticotropes and AtT-20 cells. Mol Endocrinol 3:1223-1235.

Seidah NG, Chretien M, Day R (1994) The family of subtilisin/kexin like pro-protein and pro-hormone convertases: divergent or shared functions. Biochimie (Paris) 76:197-209.

Stciner DF, Smeckens SP, Ohagi S, Chan SJ (1992) The new enzymology of precursor processing endoproteases. J Biol Chem 267:2343.3-23438.

Swank RT, Munkres KD (1971) Molecular weight analysis of oligopeptides by electrophoresis in polyacrylamide gel with sodium dodecyl sulfate. Anal Biochem 39:462-477.

Tausk FA, Milgram SL, Mains RE, Eipper BA (1992) Expression of a peptide processing enzyme in cultured cells: truncation mutants reveal a routing domain. Mol Endocrinol 6:2185-2196.

Thomas L. Leduc R, Thorne BA, Smeckens SP, Steiner DF, Thomas G (1991) Kex2-like endoproteases PC2 and PC3 accurately cleave a model prohormone in mammalian cells: evidence for a common core of neuroendocrine processing enzymes. Proc Natl Acad Sci USA 88:5297-5301.

Van de Ven WJ, Roebroek AJ, Van Duijnhoven HL (199.3) Structure and function of eukaryotic proprotein processing enzymes of the subtilisin family of serine proteases. Crit Rev Oncogenesis 4:115-136.

Vincent S, Marty L. Fort P (1903) S26 ribosomal protein RNA: an invariant control for gene regulation experiments in eucaryotic cells and tissucs. Nuclaic Acids Res 21:1498.

Wahlestedt C, Reis DJ (1993) Neuropeptide Y-related peptides and their receptors: are receptors potential therapeutic drug targets? Annu Rev Pharmacol Toxicol 32:308-352.

Wulff BS, Johansen TE, Dalboge H, OHare MM, Schwartz TW (1993) Processing of two homologous precursors, pro-neuropeptide $Y$ and pro-pancreatic polypeptide, in transfected cell lines expressing different precursor convertases. J Biol Chem 26:13327-13335.

Xu H. Shields D (1994) Prosomatostatin processing in permeabilized cells: endoproteolytic cleavage is mediated by a vacuolat ATPase that generates an acidic $\mathrm{pH}$ in the trans-Golgi network. J Biol Chem 269:22875-22881.

Zhou A, Mains RE (1994) Endoproteolytic processing of proopiomelanocortin and prohormone convertases PCl and 2 in neuroendocrine cells overexpressing prohormone convertases 1 or 2 . J Biol Chem 269: $17440-17447$

Zhou A, Bloomquist BT, Mains RE (1993) The prohormone convertases $\mathrm{PC} 1$ and $\mathrm{PC} 2$ mediate distinct endoproteolytic cleavages in a strict temporal order during proopiomelanocortin biosynthetic processing. J Biol Chem 268:1763-1769.

Zhou A, Paquet L, Mains RE (1995) Structural elements which direct specific processing of different mammalian subtilisin-like prohormone convertases. J Biol Chem 270:21509-21516. 